The Cryosphere Discuss., doi:10.5194/tc-2016-118, 2016

Manuscript under review for journal The Cryosphere

Published: 23 May 2016

(c) Author(s) 2016. CC-BY 3.0 License.

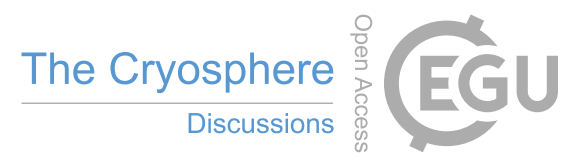

(c) (i)

\title{
1 Impact of refreezing melt ponds on Arctic sea ice basal growth
}

2 Daniela Flocco (1), Daniel L. Feltham (1), David Schröeder (1), Michel Tsamados (2)

3 (1) Centre for Polar Observations and Modelling - Department of Meteorology, University of Reading

4 (2) Centre for Polar Observations and Modelling - Department of Earth Sciences, University College

5 London

6

$7 \quad$ Corresponding author: d.flocco@reading.ac.uk

8 
The Cryosphere Discuss., doi:10.5194/tc-2016-118, 2016

Manuscript under review for journal The Cryosphere

Published: 23 May 2016

(c) Author(s) 2016. CC-BY 3.0 License.

10 Melt ponds forming over the sea ice cover in the Arctic profoundly impact the surface albedo inducing

11 a positive feedback leading to further melting.

12 Here we examine the processes involved in melt pond refreezing and their impact on basal sea ice

13 growth.

14 When ponds freeze, the ice that forms on them insulates the pond trapping it between the sea ice and

15 the ice lid. Trapped melt ponds delay basal sea ice growth in Autumn: ice thickens only after (1) the

16 pond water has been fully frozen and (2) a temperature gradient is established that will conduct heat

17 away from the ocean. Sea ice thickening in the areas where ponds are present is mainly due to the

18 pond's water refreezing. Pan-Arctic simulations with a stand-alone sea ice model and studies with a

19 high-resolution one-dimensional, three-layer refreezing model are used to study the impact on sea ice

20 growth of trapped melt ponds. Basal sea ice growth may be inhibited by up to two months. We estimate

21 an inhibited basal growth of up to $228 \mathrm{~km}^{3}$, which represents $25 \%$ of the basal sea ice growth estimated

22 by PIOMAS during the months of September and October. The brine not released due to the inhibited

23 basal growth during this period could have implications for the ocean properties and circulation. The

24 impact of trapped melt ponds has not been accounted for so far in any climate model.

29 - Melt pond refreezing inhibits basal sea ice growth.

30 - Internal temperature profile is impacted by the presence of refreezing ponds.

31 - CICE results show a total over-estimation of basal sea ice growth in Sept - Oct of up to more

32 than $200 \mathrm{~km}^{3}$. 
The Cryosphere Discuss., doi:10.5194/tc-2016-118, 2016

Manuscript under review for journal The Cryosphere

Published: 23 May 2016

(c) Author(s) 2016. CC-BY 3.0 License.

\section{Introduction}

35 The decline of Arctic Sea ice in the past 25 years has been observed and discussed extensively. In the mid-1980s multi-year ice (MYI) accounted for 70\% of total winter ice extent, whereas by the end of 2012, it had dropped to less than 20\% [Stroeve et al., 2014]. thermodynamic and dynamic processes, and the causes of the observed sea ice reduction are complex [Perovich and Richter-Menge, 2009]. Larger areas of open water observed in the summer increase the heat storage in the ocean, leading to increased water temperatures resulting in additional bottom melt of sea ice [Perovich et al., 2008, Perovich et al., 2009, Tsamados et al, 2015] and a consequent delay in winter sea ice formation.

44 The solar energy input into the ocean is affected both by the high albedo of sea ice compared to seawater (bare sea ice and snow reflectivity can be up to $\sim 85 \%$; that of water is $\sim 10 \%$ [Perovich, 2009]) and the internal absorption of radiation by sea ice. On these grounds it is straightforward to understand the importance of features such as melt ponds that form during spring from snow and ice melt because they lower the total sea ice albedo by up to $20 \%$ [Perovich et al. 2002]. Flocco et al. [2012] performed a number of sensitivity studies to evaluate the impact of including melt ponds in the sea ice component of Global Climate Models (GCMs hereafter) showing a decrease of up to $30 \%$ in the surface albedo over the summer months and an average decrease in the September sea ice volume of $40 \%$. Schroeder et al. [2014] showed that the observed September sea ice extent can be

53 skilfully predicted from the modelled spring melt pond fraction in May-June calculated with the model

54 developed by Flocco et al. [2010, 2012]. challenging. In Figure 1 though, we show one of the few available images of a refreezing pond. This is a snapshot of a video taken in September 2015 during an expedition carried out by Florida University led by David Kadko. The video was taken by William Schmoker, as part of the PolarTREC Program, in the North Canada Basin, north of Barrow, Alaska, by lowering a camera into the ice; it shows a refreezing pond of $\sim 30 \mathrm{~cm}$ depth with dendrites of length $\sim 12 \mathrm{~cm}$. 
The Cryosphere Discuss., doi:10.5194/tc-2016-118, 2016

Manuscript under review for journal The Cryosphere

Published: 23 May 2016

(c) Author(s) 2016. CC-BY 3.0 License.

61 While melt ponds enhance sea ice melting rates over summer, they also inhibit basal sea ice formation

62 during their refreezing. When melt ponds refreeze they have two effects on the internal temperature

63 profile of the ice: latent heat release inhibits cooling of the surrounding ice and salt is released in the

64 trapped pond, lowering its freezing temperature. Even once the pond is completely frozen, basal ice

65 growth cannot start until a negative temperature gradient is established at the ice-ocean interface. This

66 second stage often lasts longer than the pond's refreezing itself. The time that it takes for the

67 temperature gradient to allow ice growth to form depends on the internal temperature profile of the ice

68 and the solid fraction of the ice when the pond has refrozen. Flocco et al. [2015] introduced a high

69 resolution, explicit one-dimensional (1D) model of melt pond refreezing that demonstrates that pond

70 refreezing can delay sea ice basal growth by up to a month in areas where refrozen ponds are present.

71 Current GCMs do not include any explicit treatment of melt pond refreezing.

72 In this work we show the impact of the presence of refreezing ponds on the internal sea ice temperature

73 profile and assess the impact of melt pond refreezing on the Autumn growth of Arctic sea ice. We do

74 this by combining results from the 1D refreezing model of Flocco et al. [2015] with pan-Arctic

75 simulations from the widely used Los Alamos National Laboratory sea ice model CICE 5.04 [Hunke et

76 al., 2013]. We determine the volume of artificially high basal sea ice growth at the beginning of winter in current GCMs, where the process of pond refreezing is not accounted for.

78

79

Section 2 describes the setup of the CICE simulation and our 1D, three-layer refreezing model. Our results are presented and discussed in section 3, with conclusions presented in section 4 .

\section{Methods}

We aim to assess the bias introduced in calculations of Autumn basal sea ice volume growth in GCMs caused by the lack of treatment of refrozen ponds, using the combined results from a recently developed a 1D, three-layer model of refreezing melt ponds [Flocco et al., 2015] and the CICE sea ice model.

\subsection{CICE setup}

CICE is a dynamic-thermodynamic sea ice model designed for inclusion in a global climate model. Applying the prognostic melt pond model [Flocco et al., 2012] we performed a stand-alone sea-ice simulation for the pan-Arctic region ( $\sim 0 \mathrm{~km}$ grid resolution) over the period 1979 to September 2013 
The Cryosphere Discuss., doi:10.5194/tc-2016-118, 2016

Manuscript under review for journal The Cryosphere

Published: 23 May 2016

(c) Author(s) 2016. CC-BY 3.0 License. was used in Schroeder et al. [2014], using anisotropic rheology, but with 15 instead of 5 ice thickness categories. The larger number of categories helps reduce large jumps in the ice thickness distribution and distribution of melt ponds. The applied melt pond scheme only affects the surface albedo and the freshwater flux into the ocean, otherwise the pond layer is virtual and there is no direct impact on the temperature profiles in the ice and snow layers. ice lid on its surface. A schematic of the initial condition of the system is shown in Figure 2.

105 [Bitz and Lipscomb, 1999; Feltham et al., 2006], where $c_{i}=1.883 \times 10^{6} \mathrm{~J} /\left(\mathrm{m}^{3} \mathrm{~K}\right)$ is the specific salinity $S_{\text {bulk }}\left(\right.$ e.g. $\left.T_{L}(0)=0^{\circ} \mathrm{C}\right), \theta=T-T_{\mathrm{L}}(0)$, and $L=3.014 \times 10^{8} \mathrm{~J} \mathrm{~m}^{-3}$ is the volumetric latent heat of

$111 \quad k_{b i}=\frac{2 k_{i}+k_{a}-2 V_{a}\left(k_{i}-k_{a}\right)}{2 k_{i}+k_{a}+2 V_{a}\left(k_{i}-k_{a}\right)} k_{i}$ 
The Cryosphere Discuss., doi:10.5194/tc-2016-118, 2016

Manuscript under review for journal The Cryosphere

Published: 23 May 2016

(c) Author(s) 2016. CC-BY 3.0 License.

114 [Schwerdtfeger, 1963], where $k_{i}=1.16\left(1.91-8.66 \times 10^{-3} \boldsymbol{\theta}+2.97 \times 10^{-5} \boldsymbol{\theta}^{2}\right) \mathrm{W}(\mathrm{m} \mathrm{K})^{-1}$ is the

115 conductivity of pure ice [Sakazume and Seki, 1978], $k_{a}=0.03 \mathrm{~W}(\mathrm{~m} \mathrm{~K})^{-1}$ is the conductivity of air

116 [Weeks and Ackley, 1986], and we have assumed a constant $V_{a}=0.025$ as the fractional volume of air

117 in sea ice [Timco and Frederking, 1996].

118 At the ice lid-air interface the model solves a surface energy balance. A double radiation scheme is

119 applied to the three layers of the model [Taylor and Feltham, 2004] to calculate the radiative fluxes.

120 Continuity of temperature is maintained at the interfaces between the internal layers, which are held at

121 their liquidus temperatures. The temperature at the ice-ocean interface is set to the freezing point of the

122 ocean, which depends on the ocean salinity. The ice growth at the top and at the bottom of the trapped

123 pond is calculated from Stefan conditions at both interfaces.

124 The salinity in the pond is treated semi-analytically and presents maxima in the solutal boundary layers

125 at both ice-pond interfaces where freezing takes place and leads to salt release [Flocco et al., 2015]. A

126 fraction of the salt contained in the refreezing pond is trapped in the growing sea ice layers depending

127 on the sea ice solid fraction at the interface, therefore, in time, the bulk salinity of the lid and of the sea

128 ice at the bottom of the pond evolves. In particular, during every simulation timestep the ice bulk salinity increases creating a gradient in the lid and in the ice underneath the pond.

130 We performed simulations over 60 days of the Autumn refreezing period starting with forcing from the

$1311^{\text {st }}$ of September, with varying pond depths (10 to $\left.60 \mathrm{~cm}\right)$ and sea ice thicknesses $(0.5$ to $2.1 \mathrm{~m})$, using a

132 daily NCEP-DOE-2 climatology for atmospheric forcing [Kanamitsu et al., 2013]. In order to apply

133 representative forcing fields, 2-m air temperature and incoming long-wave and short-wave radiation

134 fluxes are spatially averaged over the area of the Arctic Ocean which is covered by melt ponds. For

135 calculating the mean forcing fields each grid point is weighted with its melt pond fraction, given by its

136 climatological mean on the $1^{\text {st }}$ of September from our CICE simulation. 
The Cryosphere Discuss., doi:10.5194/tc-2016-118, 2016

Manuscript under review for journal The Cryosphere

Published: 23 May 2016

(c) Author(s) 2016. CC-BY 3.0 License.

\subsection{Pond statistics from CICE simulation}

139 Figure 3 shows a climatology of total and trapped melt pond fraction in the Arctic based on our 35 year

140 long CICE simulation. In agreement with previous studies [Flocco et al., 2010, 2012; Schroeder et al.,

1412014 ] melt ponds start to form in the second half of May, reach a maximum fraction in mid July (35\%

142 coverage) and are mostly covered by an ice lid by the end of August. In the last decade the maximum

143 pond fraction occurs earlier showing that the melting season starts earlier than in the past. Trapped

144 ponds exist in August and September, covering up to $15 \%$ of the sea ice area during August but it is

145 worth noticing that the total and the trapped pond fraction show high inter-annual variability. While the

146 maximum total pond fraction is about $10 \%$ higher in the later decade than in the 1980 s, the trapped

147 pond fraction has decreased. We believe that this decrease is caused by the shift to a predominantly

148 thinner first year ice cover, which tends to become ponded and melt completely rather than retain pond

149 water at its surface.

150 The relative percentages of pond depths on the 1st of September, averaged over 1979-2013, occurring

151 over each of the 15 ice thicknesses used in CICE is shown in figure 4. The pond depth distribution covers the whole range from a few millimetres up to more than $1 \mathrm{~m} .31 \%$ of all ponds are shallow ponds (thinner than $10 \mathrm{~cm}$ ) and $1.9 \%$ of the ponds are deeper than $1 \mathrm{~m}$. The average pond depth is 26 $\mathrm{cm}$, a typical value found in field experiments [Polashenski, et al., 2012].

\subsection{Results from the 1D, three-layer model}

156

We use the 1D model of Flocco et al. [2015] to simulate the refreezing of ponds of variable depth over sea ice thicknesses ranging from $0.55 \mathrm{~m}$ to $2.10 \mathrm{~m}$ (the mean ice thickness in our CICE ice categories 3, 5, 6 and 8 ) for a period of 60 days. As an example, if we consider a sea ice thickness of $1.05 \mathrm{~m}$ and a melt pond of $0.3 \mathrm{~m}$, the pond freezes in 19 days (stage I), then in the following 24 days a temperature gradient in the sea ice allowing basal ice growth is established (stage II), and in the remaining 17 days of the simulation basal sea ice growth takes place (stage III).

lid interface and $55 \mathrm{psu}$ in its interior due to the rejection of salt into the pond. 
The Cryosphere Discuss., doi:10.5194/tc-2016-118, 2016

Manuscript under review for journal The Cryosphere

Published: 23 May 2016

(c) Author(s) 2016. CC-BY 3.0 License.

164 The minimum melt pond depth that we use as threshold to consider the pond to be refrozen $(2 \mathrm{~cm})$, is

165 reached before the pond effectively becomes a brine pocket and starts migrating downwards dissolving

166 the ice at the bottom of the pond (see Flocco et al. [2015] for more details). These results are shown in

167 Figure 5 where it can be observed that in our reference case (ice thickness $=1.05 \mathrm{~m}$ and pond depth $=$

$16830 \mathrm{~cm})$, the ablation of the ice at the bottom of the pond $(6 \mathrm{~cm})$ is comparable in magnitude to the basal sea ice growth $(7 \mathrm{~cm})$. In Figure 5 we also show the basal ablation at the ice ocean interface, which is a process that occurs at the beginning of each simulation while the pond is still freezing and the pond bottom temperature is above the freezing temperature of the sea water. It is interesting to notice that this process is more important for thinner pond depths: once the whole pond has frozen, the total ice thickness is smaller and the ice growth is faster, therefore the ice basal growth exceeds the basal ablation at the ice-ocean interface. The contrary happens for deeper ponds.

If we consider a layer of unponded ice with a starting ice thickness of $1.05 \mathrm{~m}$, we can compare the corresponding sea ice growth with that of the ponded ice of the same thickness. A layer of sea ice 1.05 $\mathrm{m}$ thick with no pond cover (the "slab case") would grow by $1.4 \mathrm{~cm}$ during stage I, $7.7 \mathrm{~cm}$ during stage II, plus a subsequent $11.5 \mathrm{~cm}$ during stage III, for a total of $20.6 \mathrm{~cm}$ in 60 days. Growth of unponded ice occurs at the base of the ice by freezing sea water with a prescribed salinity of 33 psu, a typical value found in the Arctic. By contrast, ice growth of the ponded ice is mainly due to the pond refreezing. In fact, the total thickness of the ice slab of $1.05 \mathrm{~m}$ overlaid by a $30 \mathrm{~cm}$ pond has a final thickness of $1.37 \mathrm{~m}$ : this figure is the sum of the lid growth, the basal growth and ablation at the bottom of the trapped pond during the pond refreezing. unponded sea ice. Refreezing of the trapped pond prevents cooling of the ice beneath the pond, creating a relatively warm layer insulating the ice beneath the pond. Basal ablation at the ocean interface occurring during pond refreezing can overcome the basal growth after the pond has refrozen. In Figure 6 we see that during the refreezing of a $30 \mathrm{~cm}$ pond, $7 \mathrm{~cm}$ of ice at the ocean interface melts, and then, once a negative temperature gradient is established, only $6 \mathrm{~cm}$ of ocean water is frozen during the remaining days of the experiment run.

191 By extending our calculations to a range of sea ice thicknesses and melt pond depths, we reach a more 
The Cryosphere Discuss., doi:10.5194/tc-2016-118, 2016

Manuscript under review for journal The Cryosphere

Published: 23 May 2016

(c) Author(s) 2016. CC-BY 3.0 License. simulating the evolution of the temperature profile in the refrozen pond and sea ice. Figure $7 \mathrm{~b}$ shows the inhibited basal ice growth for ponded ice for the same experiment during stage I and stage II: this is the amount of basal sea ice growth in a slab of ice during time equivalent to stage I and stage II. Figure $7 \mathrm{~b}$ plus the decreased sea ice basal growth happening in stage III, when basal growth occur in both cases. The same holds for figure $7 \mathrm{c}$ and $7 \mathrm{~d}$.

For simulations with a fixed pond depth of $0.3 \mathrm{~m}$ over varying sea ice thickness we see that the inhibiting effect of pond refreezing on basal sea ice growth is a function of the underlying ice thickness (Fig. 7c). The ratio of inhibited growth between Stage I and Stage II depends on the initial ice thickness (Fig. 7d). For sea ice thickness greater than $1.4 \mathrm{~m}$ basal growth is not observed within the 60 days of model simulation. This is because it takes longer for the heat to be transferred to the ocean through thicker ice and therefore it takes longer for basal growth to start.

\subsection{Combining results from $1 D$ model and CICE}

209 We implemented solutal boundary layers into the melt pond refreezing scheme of Flocco et al. [2012] in the CICE sea ice model. This allows us to determine the inhibited ice growth during the pond refreezing process (Stage I) for our CICE model. We have compared the inhibited basal sea ice growth of the 1D model corresponding to Stage I with our modified CICE model for a range of initial pond and ice thicknesses and the two models present similar results, suggesting that the modifications to CICE

214 are adequate for Stage I (Figure 8). This figure shows a comparison for a 4 ice thickness categories 215 (0.55 m, $1.05 \mathrm{~m}, 1.35 \mathrm{~m}, 2.1 \mathrm{~m})$ and pond depths ranging from 30 to $60 \mathrm{~cm}$. Thinner ponds have been omitted from the comparison because their life time is overestimated in CICE due to the redistribution of melt water from thicker to thinner ice categories. 
The Cryosphere Discuss., doi:10.5194/tc-2016-118, 2016

Manuscript under review for journal The Cryosphere

Published: 23 May 2016

(c) Author(s) 2016. CC-BY 3.0 License.

221 In order to find the total inhibited growth due to the presence of melt ponds we combine the CICE

222 estimate of the inhibited growth in Stage I with the ratio of inhibited growth in Stage II to Stage I from

223 the 1D model (Figure 7b+d). For example, for a pond depth of $30 \mathrm{~cm}$ and sea ice thickness of $1.05 \mathrm{~m}$

224 the ratio between the pond freezing time (Stage I) and the time to reach a sea ice growth temperature

225 gradient (Stage II) is about 1:5. The inhibited growth of $1.4 \mathrm{~cm}$ during Stage I from the modified

226 CICE model corresponds to an inhibited growth of $7.7 \mathrm{~cm}$ during Stage II from the 1D model.

227 Integrating the CICE results for the inhibited growth corresponding to Stage I over the whole Arctic,

228 we derive a 1979-2013 average value of $23+/-9 \mathrm{~km}^{3}$ with a maximum value of $43 \mathrm{~km}^{3}$ in 1983 .

229 Applying the ratio between Stage I and Stage II from our 1D model for each pond depth and ice

230 thickness category individually, we calculate the total inhibited ice growth. Figure 9 shows the time

231 series of inhibited ice growth where we observe a decreasing trend of $-4.4 \mathrm{~km}^{3} /$ year with considerable

232 interannual variability. The trend arises because the ice cover has thinned and thus the required

233 temperature profile in the ice for refreezing is more quickly established. The thinner ice is also more

234 likely to melt completely.

Over 1979-2013 the mean inhibited ice growth is $126+/-55 \mathrm{~km}^{3}$ with a maximum value of $228 \mathrm{~km}^{3}$ in 1983. In Figure 10 we show the magnitude of the local inhibited basal ice growth for the extreme year 1983.In this map the grid cell averaged inhibited ice growth is above $10 \mathrm{~cm}$ for large areas in the

Canadian Arctic and can reach values as high as $20 \mathrm{~cm}$.

\section{Conclusion}

The presence of refreezing melt ponds delays basal sea ice growth in Autumn: ice only thickens after

241 (1) the pond water has been fully frozen and (2) a temperature gradient within the ice has been

242 established that will conduct heat from the ocean to the atmosphere. In addition, melt ponds cause basal

243 melt because the pond bottom temperature is above the sea water freezing temperature. These

244 processes have not been accounted for so far in any climate model. A stand-alone simulation with a

245 version of the Los Alamos National Laboratory CICE sea ice model shows an overestimated basal sea

246 ice growth of around $20 \mathrm{~km}^{3}$ due to not considering the first process (pond refreezing). The impact of

247 the second process cannot be determined from CICE, however, using the pond depth distribution from

248 CICE, simulations with a 1D melt pond refreezing model show that the impact on refreezing of the 
The Cryosphere Discuss., doi:10.5194/tc-2016-118, 2016

Manuscript under review for journal The Cryosphere

Published: 23 May 2016

(c) Author(s) 2016. CC-BY 3.0 License.

251 in Autumn over the Arctic basin. These values range from $12 \%$ to $23 \%$ of the amount of sea ice growth

252 estimated from PIOMAS in the same period (September-October) [Zhang et al., 2003].

253 The total ice mass balance is not too strongly affected by neglecting the refreezing process. Our CICE

254 simulations show that pond refreezing contributes $113 \mathrm{~km} 3$ of ice, which is similar to the mean

255 overestimation of basal ice growth of $128 \mathrm{~km} 3$. However, the source of ice volume increase in Autumn

256 is of relevance to related processes: our results suggest existing estimates of negative buoyancy

257 production at the ice-ocean interface due to salt release during sea ice growth have been

258 overestimated in models.

259 There is a decreasing volume of refreezing ponds during the last decade, primarily due to the shift from

260 a permanent to a more seasonal Arctic sea ice cover. The majority of ponds are present on thin ice,

261 which are more likely to disappear at the end of summer. While the overestimation of basal ice growth

262 by ignoring pond refreezing has decreased in the last few decades, the overestimated basal growth is

263 not negligible.

267 We would like to acknowledge the Natural Environmental Research Council for supporting this work.

268 The CICE model with the supportive documentation can be found at 269 http://oceans11.lanl.gov/drupal/CICE. The NCEP data are available for download at www.esrl.noaa.gov/psd/data/gridded/data.ncep.reanalysis2.html. 
The Cryosphere Discuss., doi:10.5194/tc-2016-118, 2016

Manuscript under review for journal The Cryosphere

Published: 23 May 2016

(c) Author(s) 2016. CC-BY 3.0 License.

Bailey, E., D. L. Feltham, and P. R. Sammonds (2010), A model for the consolidation of rafted sea ice, J. Geophys. Res., 115, C04015, doi:10.1029/2008JC005103.

Bitz, C., and W. Lipscomb (1999), An energy-conserving thermodynamic model of sea ice, J. Geophys. Res., 104, 15,669-15,677, doi:10.1029/1999JC900100.

Feltham, D. L., Untersteiner, N., Wettlaufer, J. S. and Worster, M. G. (2006) Sea ice is a mushy layer. Geophysical Research Letters, 33 (14). L14501. ISSN 0094-8276 doi: 10.1029/2006GL026290. doi:10.1029/2009JC005568.

Flocco, D., D. Schroeder, D. L. Feltham, and E. C. Hunke (2012), Impact of melt ponds on Arctic sea ice simulations from 1990 to 2007, J. Geophys. Res., doi:10.1029/2012JC008195.

Flocco, D., D. L. Feltham, E. Bailey, and D. Schroeder (2015), The refreezing of melt ponds on Arctic

Kanamitsu, M., W. Ebisuzaki, J. Woollen, S-K Yang, J.J. Hnilo, M. Fiorino, and G. L. Potter, NCEPDOE AMIP-II Reanalysis (R-2): 1631-1643, Bulletin of the American Meteorological Society, (2002, updated 2013). Science, Vol. 1: $417-441$.

Perovich, D. K., J. A. Richter-Menge, K. F. Jones, and B. Light (2008), Sunlight, water, and ice: Extreme Arctic sea ice melt during the summer of 2007, Geophys. Res. Lett., 35, L11501, doi:10.1029/2008GL034007. 
The Cryosphere Discuss., doi:10.5194/tc-2016-118, 2016

Manuscript under review for journal The Cryosphere

Published: 23 May 2016

(c) Author(s) 2016. CC-BY 3.0 License.

surface conditions during summer, J. Geophys. Res., 107 (C10), 8048, doi:10.1029/2000JC000449. and evolution, J. Geophys. Res., 117, C01001, doi:10.1029/2011JC007231.

Sakazume, S., and N. Seki (1978), Thermal properties of ice and snow at low temperature region, Bull. JSME, 44(382), 2059-2069. 44(382), 2059-2069.

Stroeve, J. C., T. Markus, L. Boisvert, J. Miller, and A. Barrett (2014), Changes in Arctic melt season and implications for sea ice loss, Geophys. Res. Lett., 41, 1216-1225, doi:10.1002/2013GL058951.

Taylor, P. D., and D. L. Feltham (2004), A model of melt pond evolution on sea ice, J. Geophys. Res., 109, C12007, doi:10.1029/2004JC002361.

Timco, G. W., and R. M. W. Frederking (1996), A review of sea ice density, Cold Reg. Sci. Technol., 24, 1-6, doi: 10.1016/0165-232X(95)00007-X. melt of Arctic sea ice in a state of the art sea ice model, Phil. Trans. R. Soc. A 2015373 20140167; DOI: 10.1098/rsta.2014.0167. 
The Cryosphere Discuss., doi:10.5194/tc-2016-118, 2016

Manuscript under review for journal The Cryosphere

Published: 23 May 2016

(c) Author(s) 2016. CC-BY 3.0 License.

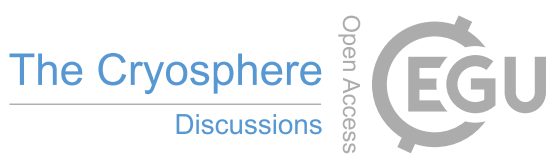

(c) (i)

323 Zhang, J and D.A. Rothrock, (2003) Modeling global sea ice with a thickness and enthalpy distribution

324 model in generalized curvilinear coordinates, Mon. Wea. Rev. 131(5), 681-697 (updated 2012).

325 
The Cryosphere Discuss., doi:10.5194/tc-2016-118, 2016 Manuscript under review for journal The Cryosphere

Published: 23 May 2016

(c) Author(s) 2016. CC-BY 3.0 License.

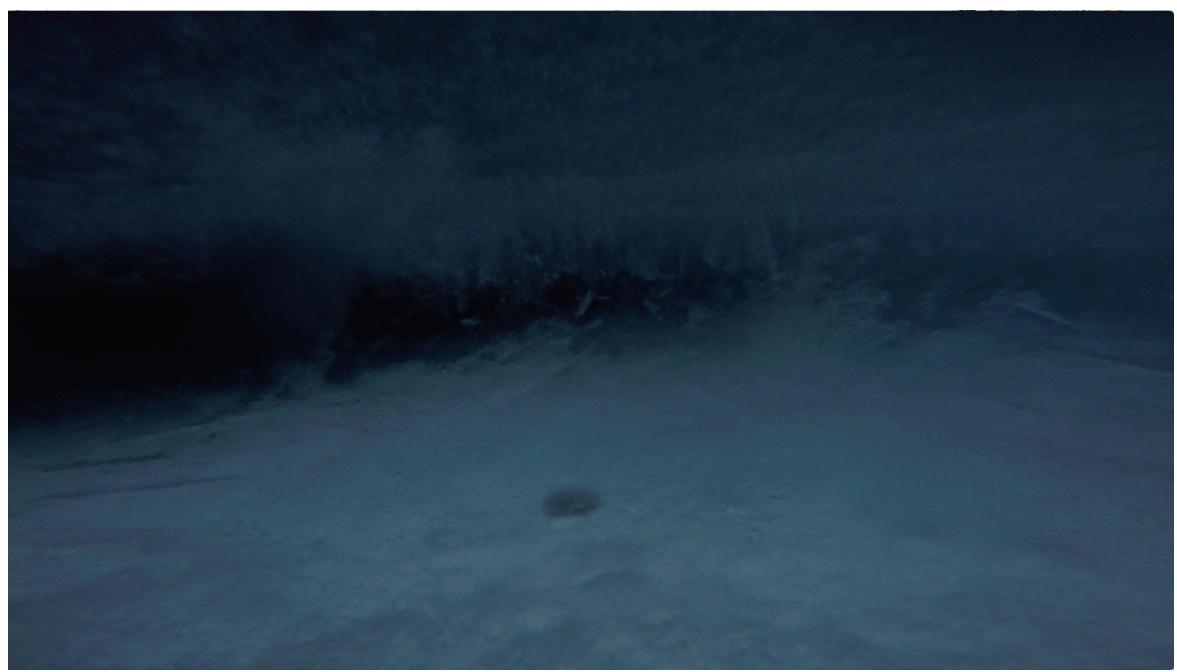

328 Figure 1: Refreezing pond from field observation (Bill Schmoker, PolarTREC 2015, Courtesy of 329 Arctic Research Consortium of the United States.).

330

331

332 
The Cryosphere Discuss., doi:10.5194/tc-2016-118, 2016

Manuscript under review for journal The Cryosphere

Published: 23 May 2016

(c) Author(s) 2016. CC-BY 3.0 License.
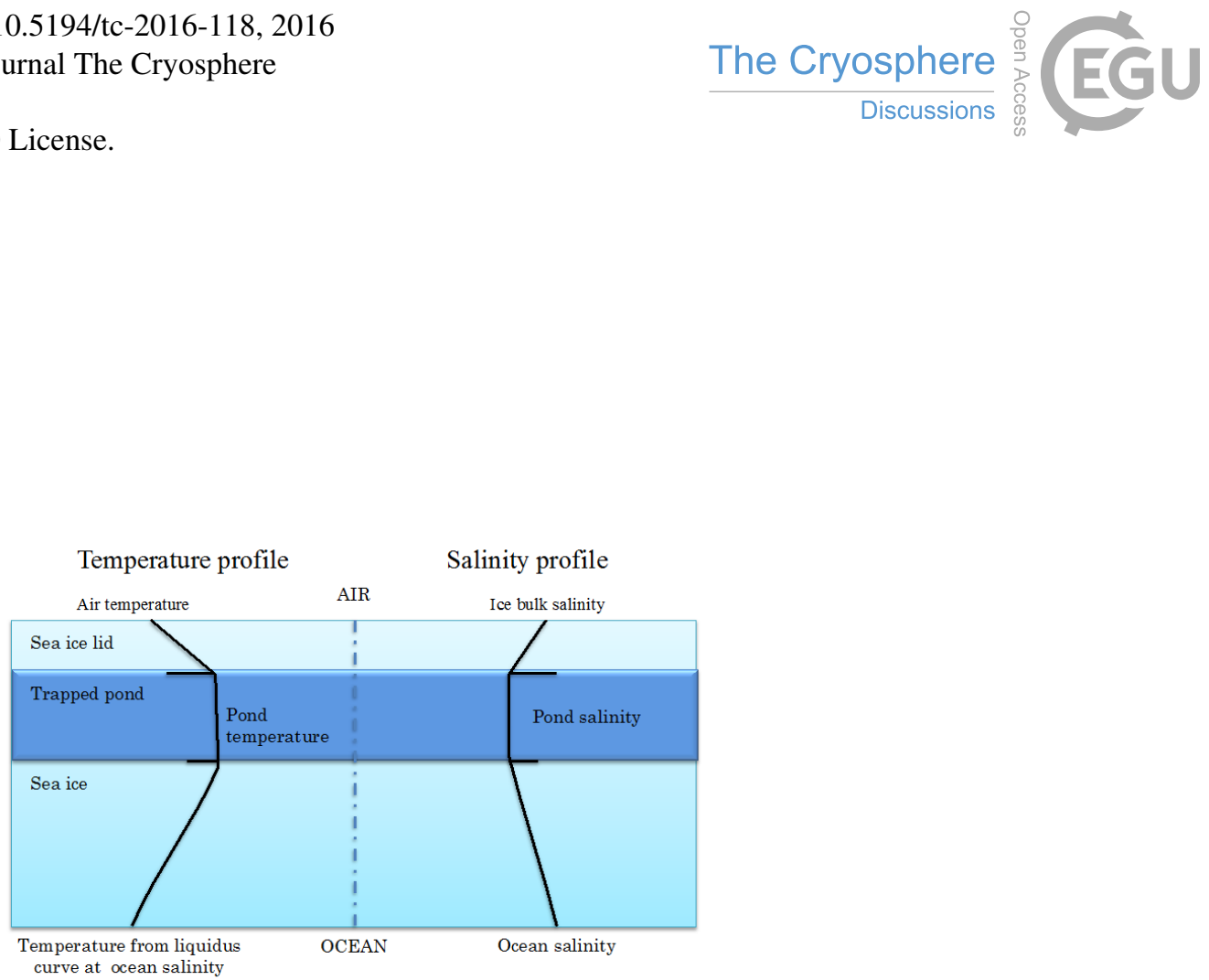

Figure 2: Configuration of the phases in the one-dimensional, three-layer model: the left panel shows the temperature profile in the three layers: ice lid, pond and sea ice. The right panel shows the salinity profile in the three layers. The temperature minima at the pond interfaces are due to the high salinity at the upper and lower boundary layers due to salt rejection from ice formation. 
The Cryosphere Discuss., doi:10.5194/tc-2016-118, 2016

Manuscript under review for journal The Cryosphere

Published: 23 May 2016

(c) Author(s) 2016. CC-BY 3.0 License.

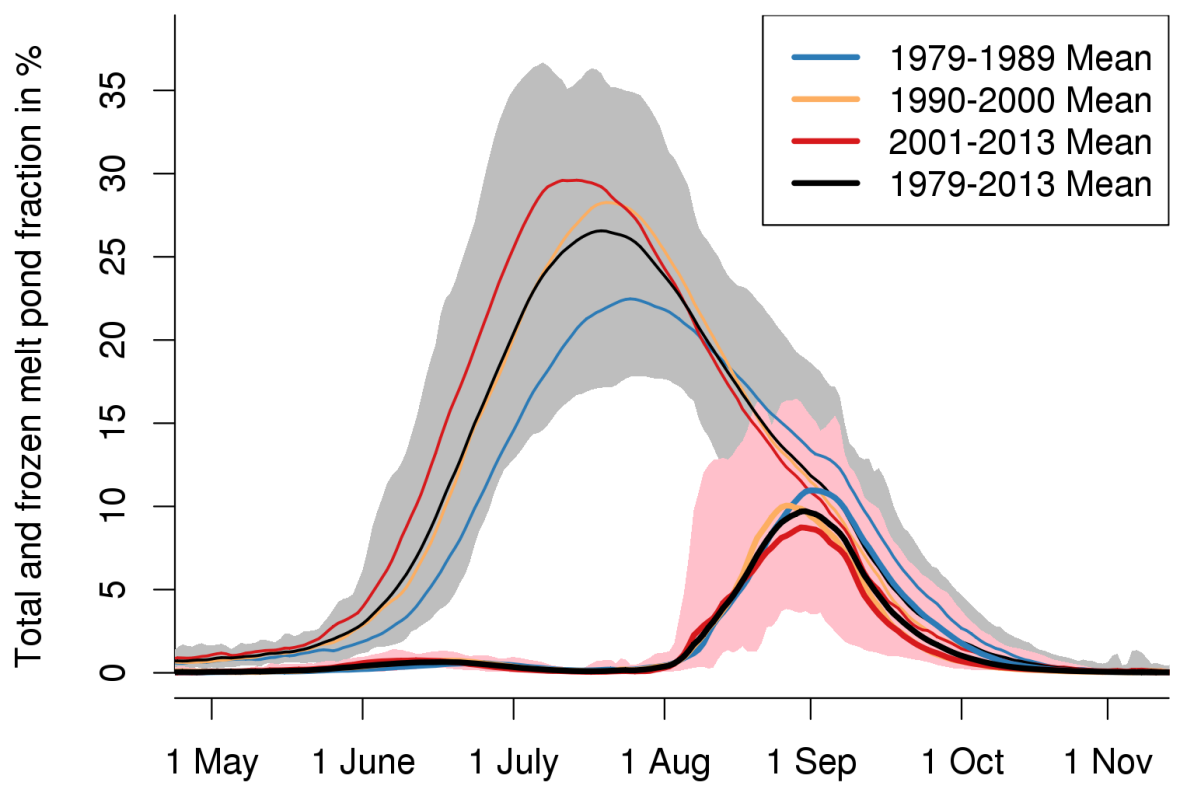

Figure 3: Total and frozen melt pond surface fractions in \% (respectively the grey and the pink areas). The average values for the decades from 1979 to 2013 are superimposed over the pond

348 area and the refrozen pond area. 
The Cryosphere Discuss., doi:10.5194/tc-2016-118, 2016

Manuscript under review for journal The Cryosphere

Published: 23 May 2016

(c) Author(s) 2016. CC-BY 3.0 License.

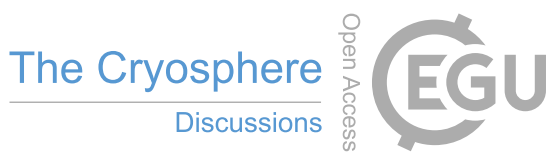
(c) (i)

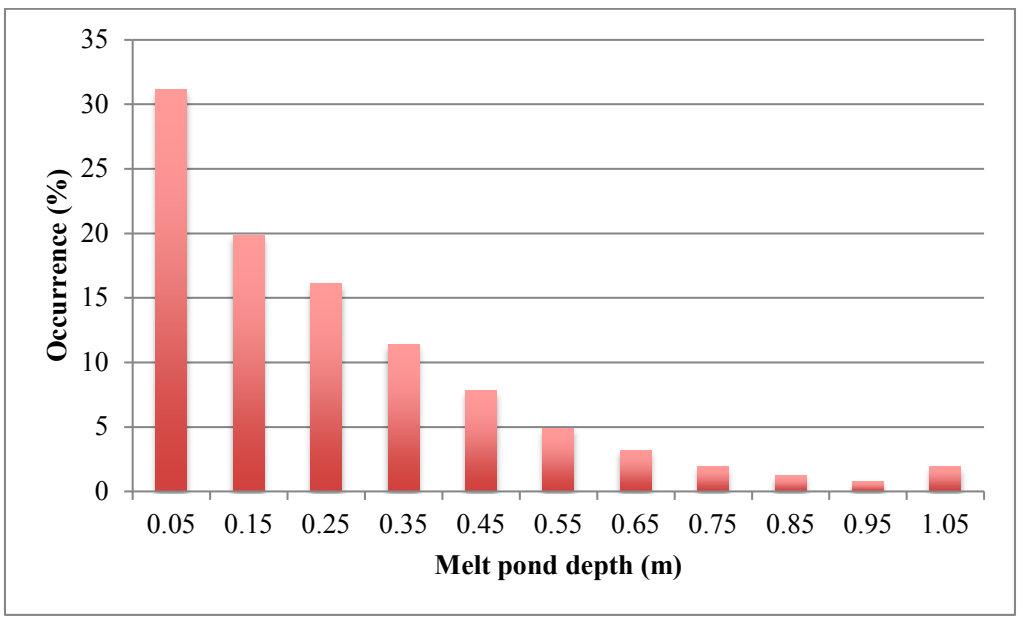

354 Figure 4: Artic basin-wide distribution of pond depth on $1^{\text {st }}$ September (average of 1979-2013) 355 over all ice thickness categories for the CICE model. 
The Cryosphere Discuss., doi:10.5194/tc-2016-118, 2016

Manuscript under review for journal The Cryosphere

Published: 23 May 2016

(c) Author(s) 2016. CC-BY 3.0 License.

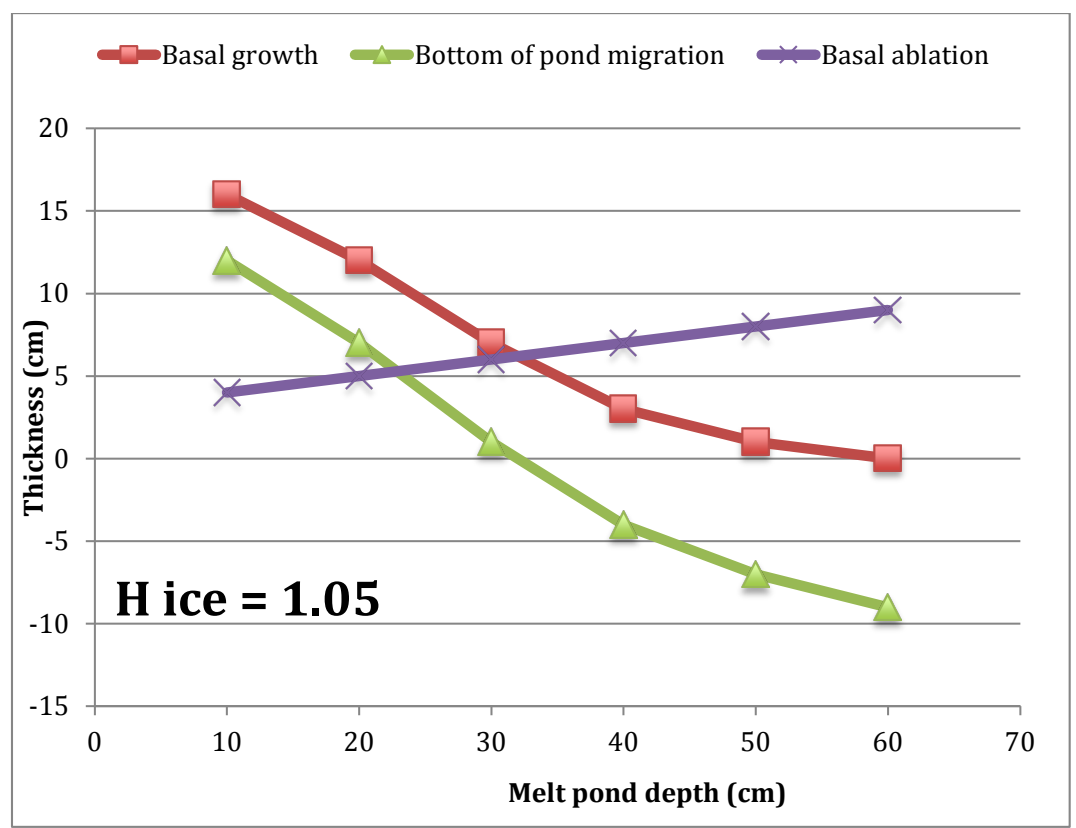

Figure 5: Bottom of the pond ablation, basal ice growth and basal ablation at the ocean interface at the end of the 60 days simulation beginning on $1^{\text {st }}$ September for an initial ice thickness of 1.05 
The Cryosphere Discuss., doi:10.5194/tc-2016-118, 2016

Manuscript under review for journal The Cryosphere

Published: 23 May 2016

(c) Author(s) 2016. CC-BY 3.0 License.
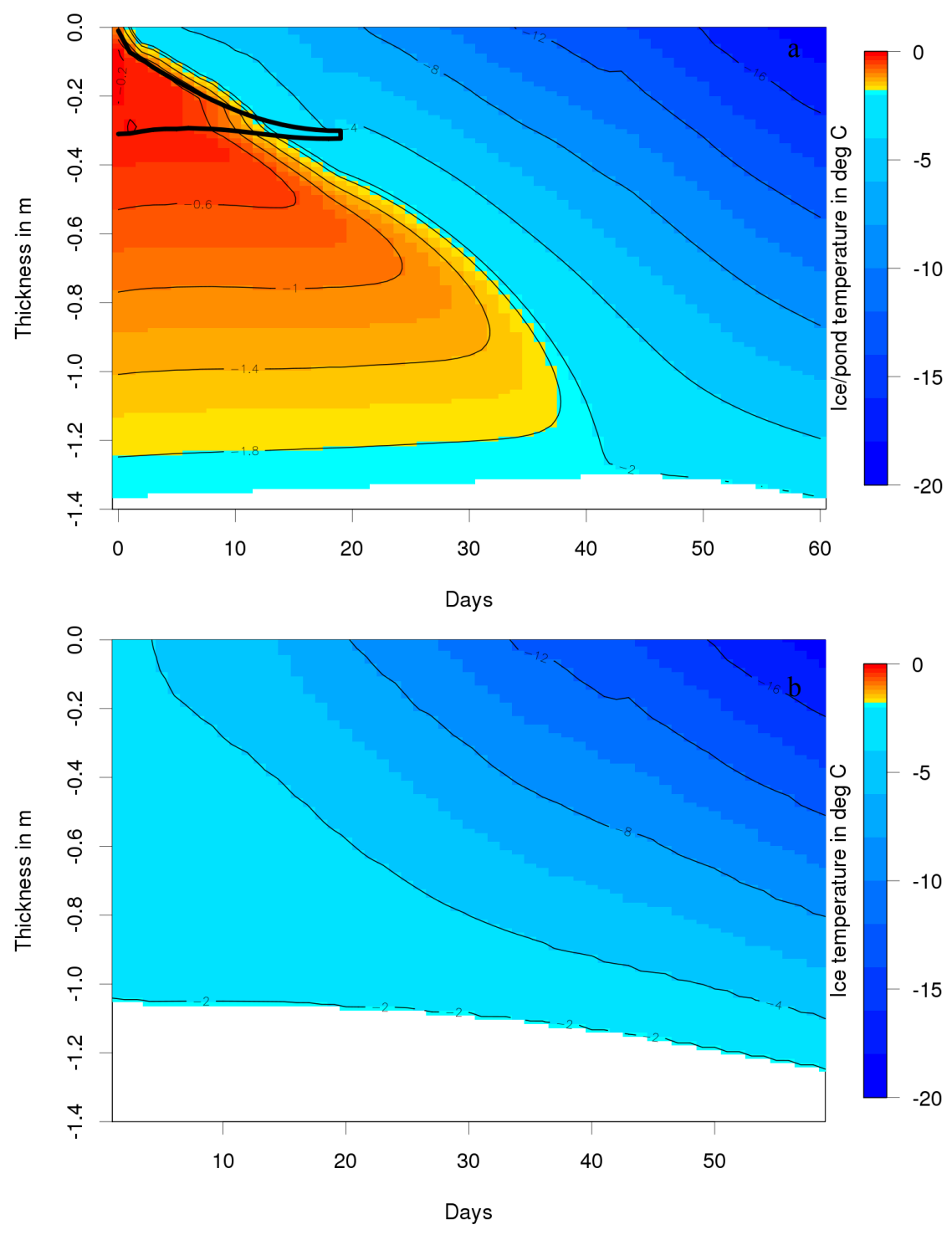

Figure 6: (a) Sea ice internal temperature profile for a refreezing pond of $30 \mathrm{~cm}$ over an ice layer of $1.05 \mathrm{~m}$. The bold black lines denote the phase boundaries at the top and bottom of the trapped pond. (b) Sea ice internal temperature profile ice layer of $1.05 \mathrm{~m}$ 
The Cryosphere Discuss., doi:10.5194/tc-2016-118, 2016

Manuscript under review for journal The Cryosphere

Published: 23 May 2016

(c) Author(s) 2016. CC-BY 3.0 License.
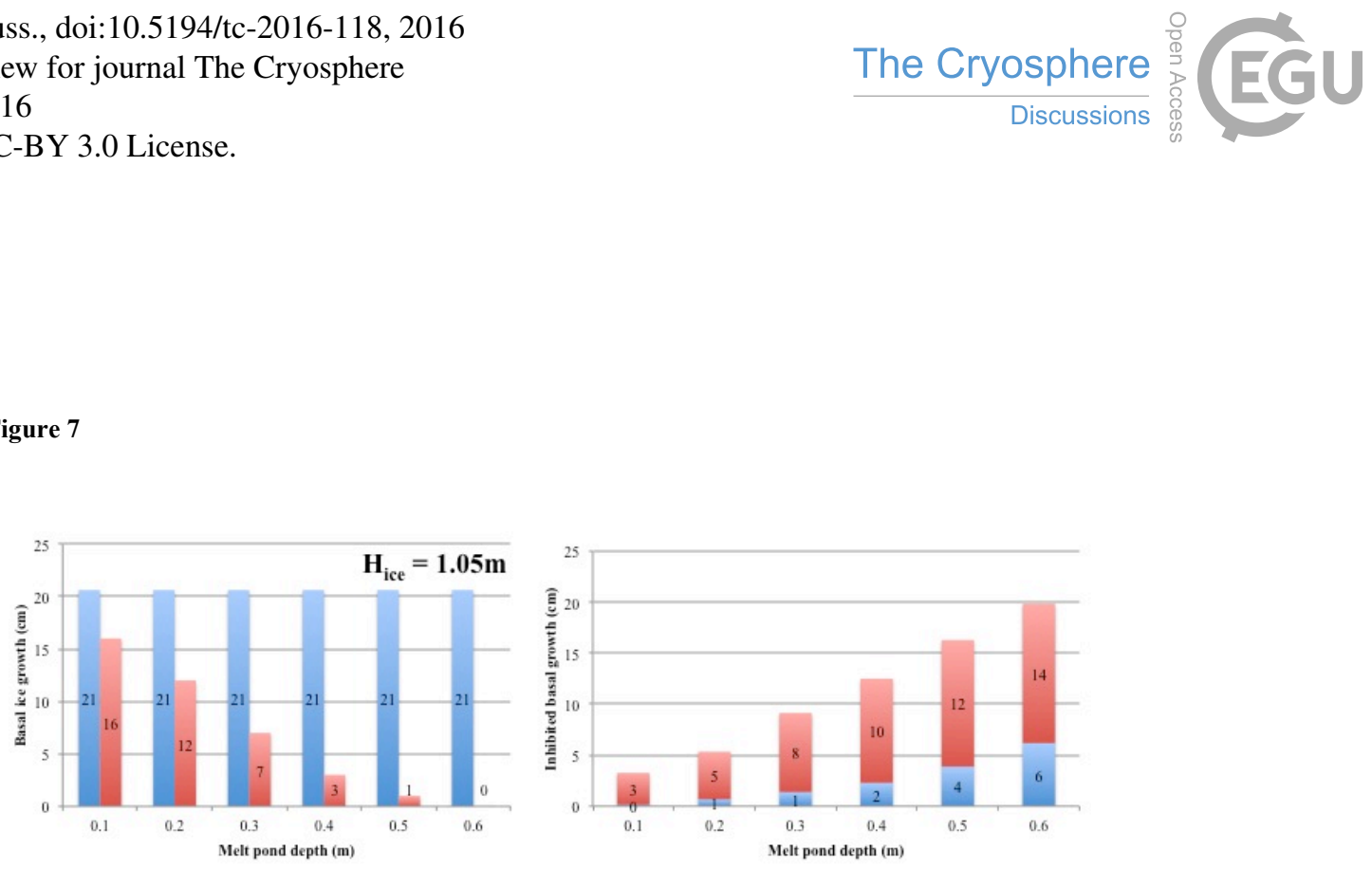

"Slab growth "Basal growth

"Refreczing pond "Establishing gradient
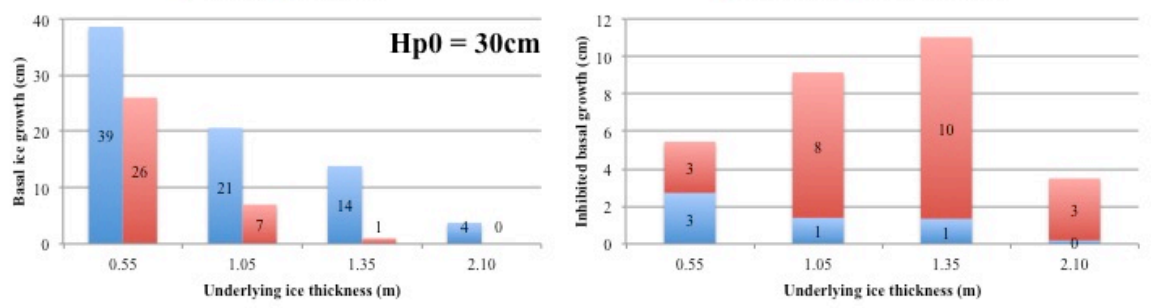

380 Figure 7 (a, b) Basal sea ice growth and inhibited basal growth for the refreezing pond model in comparison with a slab model that grows by $21 \mathrm{~cm}$ over 60 days for varying pond depths; (c, d) Basal sea ice growth and inhibited basal growth for the refreezing pond model with a $0.3 \mathrm{~m}$ pond over a $1.05 \mathrm{~m}$ ice slab in comparison with a slab model over 60 days for varying ice thicknesses. See text for description. 
The Cryosphere Discuss., doi:10.5194/tc-2016-118, 2016

Manuscript under review for journal The Cryosphere

Published: 23 May 2016

(c) Author(s) 2016. CC-BY 3.0 License.

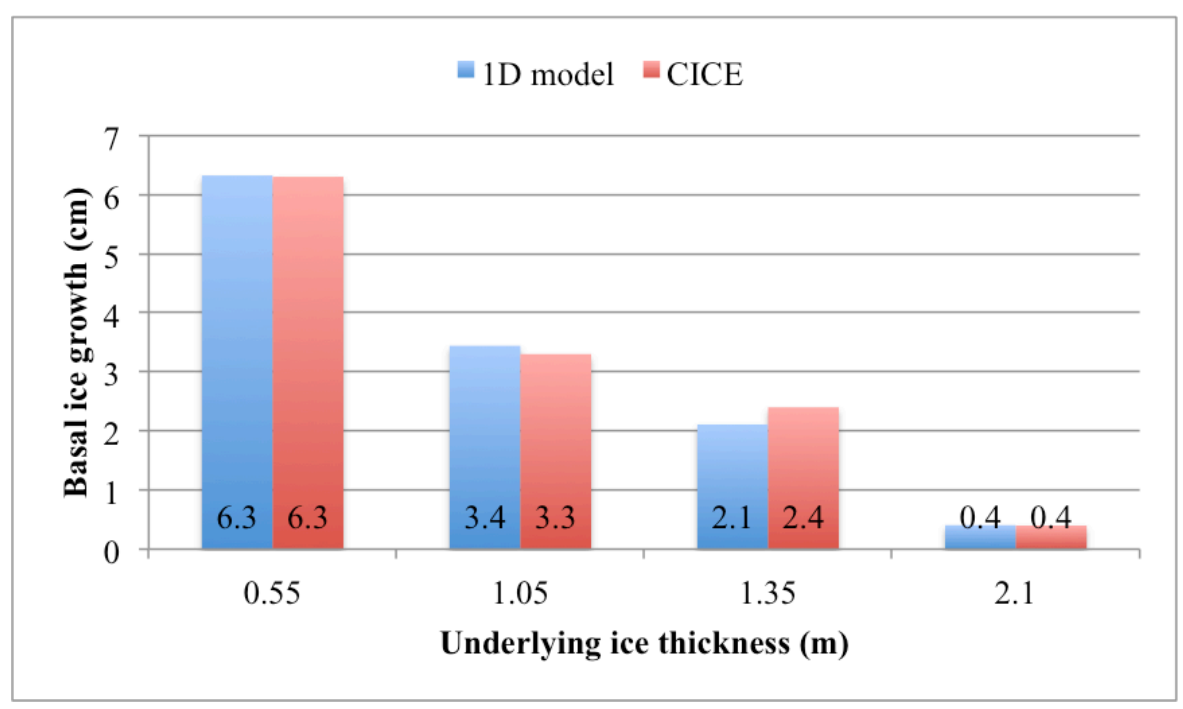

Figure 8: Comparison of inhibited basal ice growth during pond refreezing (Stage I) in the 1D model and in CICE: this is the basal growth that would occur in the absence of a refreezing pond. This histogram uses the averaged value of ice growth in the 1D, three layer model averaged over 
The Cryosphere Discuss., doi:10.5194/tc-2016-118, 2016

Manuscript under review for journal The Cryosphere

Published: 23 May 2016

(c) Author(s) 2016. CC-BY 3.0 License.

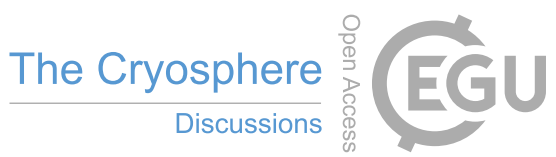
(c) (i)

$394 \quad$ Figure 9

395

396

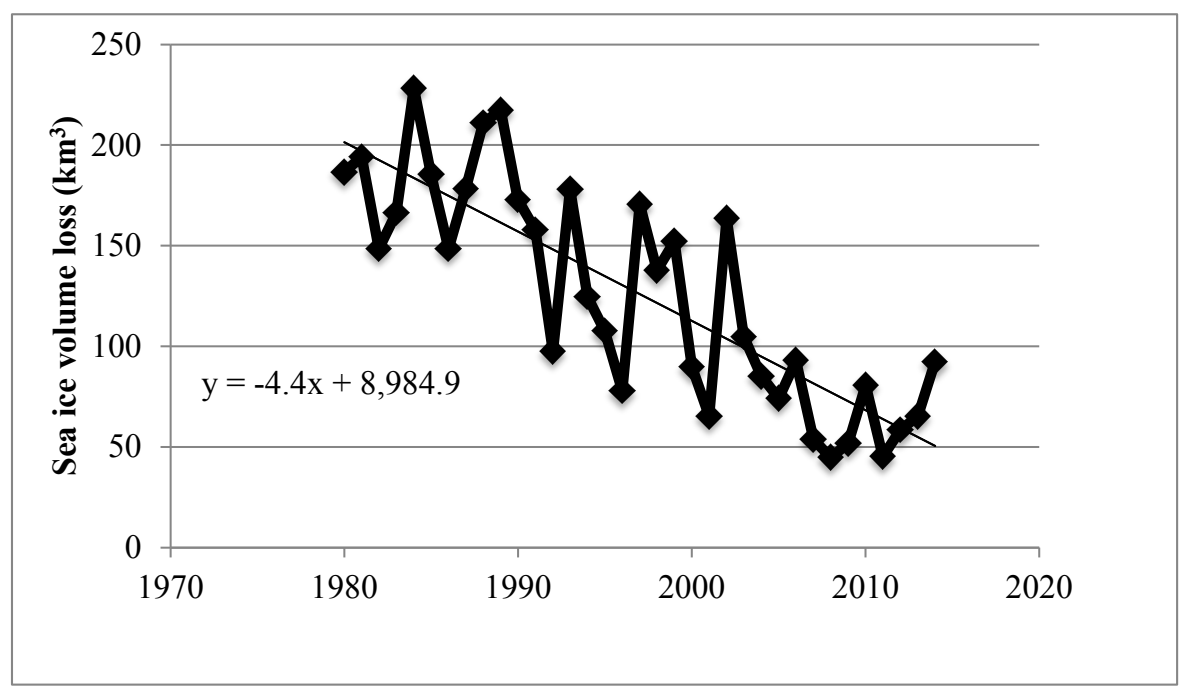

397

398

Figure 9: Time series of total inhibited growth from 1979 to 2013. 
The Cryosphere Discuss., doi:10.5194/tc-2016-118, 2016

Manuscript under review for journal The Cryosphere

Published: 23 May 2016

(c) Author(s) 2016. CC-BY 3.0 License.

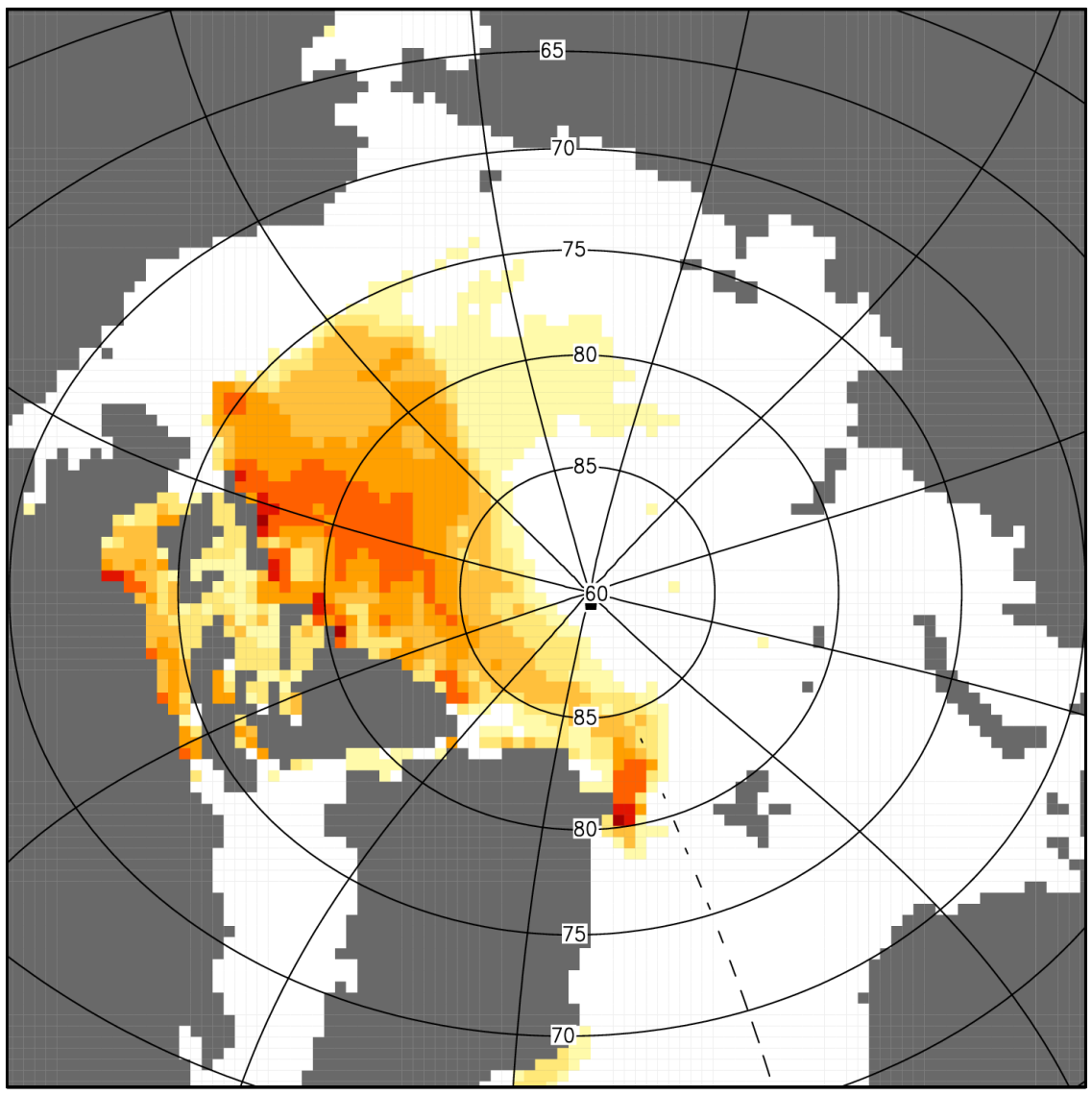

Total inhibited ice growth in $\mathrm{cm}$

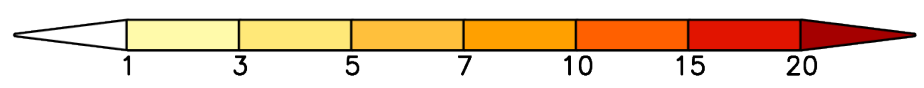

402 Figure 10: Total inhibited sea ice growth volume in 1983 for both Stage I (refreezing of pond, as simulated in CICE), and Stage II (establishing of temperature profile for growing of ice, as calculated using relationship between growth during Stages I and II for individual pond depths 405 and ice thickness categories). The spatially integrated inhibited growth amounts to $228 \mathrm{~km}^{3}$ of sea 406 ice. 
The Cryosphere Discuss., doi:10.5194/tc-2016-118, 2016

Manuscript under review for journal The Cryosphere

Published: 23 May 2016

(c) Author(s) 2016. CC-BY 3.0 License.

Figures captions

411 Figure 1: Refreezing pond from field observation (Bill Schmoker, PolarTREC 2015, Courtesy of Arctic Research Consortium of the United States.).

Figure 2: Configuration of the phases in the one-dimensional, three-layer model: the left panel shows

Figure 3: Total and frozen melt pond surface fractions in \% (respectively the grey and the pink areas).

The average values for the decades from 1979 to 2013 are superimposed over the pond area and the refrozen pond area.

Figure 4: Artic basin-wide distribution of pond depth on 1st September (average of 1979-2013) over all ice thickness categories for the CICE model.

Figure 5: Bottom of the pond ablation, basal ice growth and basal ablation at the ocean interface at the end of the 60 days simulation beginning on 1st September for an initial ice thickness of $1.05 \mathrm{~m}$ and a range of melt pond depths. the temperature profile in the three layers: ice lid, pond and sea ice. The right panel shows the salinity profile in the three layers. The temperature minima at the pond interfaces are due to the high salinity at the upper and lower boundary layers due to salt rejection from ice formation.

Figure 6: (a) Sea ice internal temperature profile for a refreezing pond of $30 \mathrm{~cm}$ over an ice layer of $1.05 \mathrm{~m}$. The bold black lines denote the phase boundaries at the top and bottom of the trapped pond. (b) Sea ice internal temperature profile ice layer of $1.05 \mathrm{~m}$

Figure 7: $(a, b)$ Basal sea ice growth and inhibited basal growth for the refreezing pond model in comparison with a slab model that grows by $21 \mathrm{~cm}$ over 60 days for varying pond depths; (c, d) Basal sea ice growth and inhibited basal growth for the refreezing pond model with a $0.3 \mathrm{~m}$ pond over a $1.05 \mathrm{~m}$ ice slab in comparison with a slab model over 60 days for varying ice thicknesses. See text for description.

Figure 8: Comparison of inhibited basal ice growth during pond refreezing (Stage I) in the 1D model and in CICE: this is the basal growth that would occur in the absence of a refreezing pond. 
The Cryosphere Discuss., doi:10.5194/tc-2016-118, 2016

Manuscript under review for journal The Cryosphere

Published: 23 May 2016

(c) Author(s) 2016. CC-BY 3.0 License.

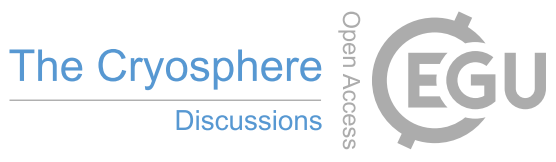

(c) (i)

436

This histogram uses the averaged value of ice growth in the $1 \mathrm{D}$, three layer model

437

averaged over a range of pond depths of $30-60 \mathrm{~cm}$.

438 Figure 9: Time series of total inhibited growth from 1979 to 2013.

439 Figure 10: Total inhibited sea ice growth volume in 1983 for both Stage I (refreezing of pond, as simulated in CICE) and Stage II (establishing of temperature profile for growing of ice, as

441 calculated using relationship between growth during Stages I and II for individual pond

442 depths and ice thickness categories). The spatially integrated inhibited growth amounts to

443 $228 \mathrm{~km} 3$ of sea ice. 